\title{
LA CREATIVIDAD COLECTIVA (EN UNA SOCIEDAD CANSADA).
}

\author{
INMACULADA RODRÍGUEZ-CUNILL \\ Universidad de Sevilla
}

\begin{abstract}
Resumen
¿Cómo opera la creatividad? Este artículo trata de evidenciar conflictos, cambios y mutaciones que explican los trasvases entre la creación colectiva e individual, primero rastreando los fundamentos científicos de la creatividad humana, en un segundo lugar a través de las vanguardias artísticas del siglo XX y la introducción de elementos interactivos y finalmente contextualizando ideológicamente las condiciones artísticas ligadas a la situación actual planetaria: el comportamiento del mercado artístico, su saturación, el siguiente paso a la fórmula "todo ser humano es un artista", hasta llegar a reflexiones sobre qué nos conviene considerar artístico para el objetivo de la supervivencia global.
\end{abstract}

$$
\text { Palabras Clave }
$$

Artes colectivas, filosofía del arte, arte contemporáneo.

$$
\text { THE COLLECTIVE CREATIVITY (IN A TIRED SOCIETY). }
$$

Abstract

How does creativity work? This article deals with conflicts, changes and mutations that explain transfers between collective and individual creation, firstly by tracing the scientific basis of human creativity, on the other hand through the avant-gardes from the past century, the use of interactive elements and eventually by contextualizing ideologically the artistic conditions linked to the current planetary situation: the behavior of the artistic market, its saturation, the next step to the sentence "every human being is an artist", until reaching reflections on what we should consider "artistic", to the aim of the global survival.

$$
\text { Key Words }
$$

Collaborative art, contemporary art, philosophy of art.

\section{Fundamentos para la creatividad}

¿Qué es la creatividad artística? Para conocer los fundamentos científicos de la creatividad, dos han sido las líneas más fructíferas: el estudio de las biografías de hombres y mujeres sobresalientes en originalidad y los procesos del pensamiento. Vayamos a la primera de las cuestiones. Aquellos individuos que han pasado a la historia occidental como reveladores de nuevas concepciones, aquellos que han aportado visiones radicalmente nuevas, a menudo han sido estudiantes mediocres. Tampoco parece haber relación entre los resultados de los tests de coeficiente intelectual con una originalidad relevante.

"En el contexto americano, los jóvenes científicos de gran renombre son en general, estudiantes "B+": los que trabajan duro cuando un tema les interesa mucho, pero que de lo contrario hacen lo mínimo. La ciencia aflora en la vida de estos individuos cuando descubren que, en vez 
de asimilar el conocimiento creado por otros, pueden crear conocimiento por sí mismos, y a partir de ese momento, quedan enganchados"1.

Creo que es aquí donde radica la cuestión. Cuando un individuo encuentra su expresión propia y se libera de la idea de basarse en lo que otros dicen, surgen matices creativos relevantes. La solución de la propia expresión, si la cuestión es ser creativa, no se halla en la aceptación de lo que otros compañeros escriben.

"Los estudios más minuciosos sobre el pensamiento son los que señalan las tensiones que subyacen a este esfuerzo creativo. Los matemáticos han participado en algunos de los más elocuentes; y una de sus características es el énfasis que ponen en el proceso de "incubación". A menudo, después de haber luchado con un problema y haberlo dejado de lado, los matemáticos encuentran que la solución les llega de forma totalmente inesperada, en un instante. La consecuencia clara es que nuestro cerebro se muestra más eficiente cuando se le deja alternar las fases de concentración intensa con aquellas en las que no ejercemos control consciente alguno"2

Desde luego, el pensamiento lógico no es el que se impone en algunas de las fases del proceso creativo. Los poderes narrativos imponen un control que es el que se debe romper en el mismo hecho de percibir. Crear es dar una nueva visión, y eso supone subvertir el pensamiento cotidiano que nos guía, la sabiduría convencional. No se trata de locura. Tal vez es una necesidad de ciertos individuos para salvar la locura, pero que se puede transformar dentro de nuestra sociedad en un germen operativo de novedades aprovechables en nuestro progreso, en nuestra intención de ser mejores mujeres y hombres.

Desde el terreno de la lógica, no cabría la siguiente afirmación pero sí desde el de la creación artística y la iluminación: "Puede no haber una razón para decir algo hasta después de haberlo dicho" 3 . La lógica impone un desarrollo lineal y se revuelve contra esta frase. A través de un pensamiento lógico, a partir de los datos ofrecidos y asumidos con anterioridad, procedo a sacar conclusiones. En el universo de la creación, de la mística, y del pensamiento divergente, hay cosas que, simplemente, ocurren, y son anécdotas que toman tal fuerza, que son capaces de generar no sólo creaciones artísticas o textos de visionarios, sino también teorías científicas. De hecho, en todo el proceso constructivo del pensamiento moderno el trinomio tesis-antítesissíntesis está presente. Pero ¿de dónde sale la hipótesis? Carecemos de la lógica para generar las hipótesis, puesto que la lógica se basa siempre en los pasos precedentes. En el germen de una hipótesis, se encuentra la provocación, la anécdota. El motor inicial y primigenio que da lugar más tarde a nuevas teorías, se resiste a una integración en el ámbito de la lógica. El pensamiento lógico queda aislado y se pone en juego el pensamiento lateral ${ }^{4}$ La dimensión creativa, no la lógica, se impone en el inicio de actividades que pueden luego ser analizadas desde la lógica, pero insisto en que el uso de la lógica se efectúa a posteriori. En la primera etapa del pensamiento, la de la percepción, podemos estar utilizando muchos patrones posibles. Sin embargo, lo habitual es recurrir siempre a patrones análogos, que no nos ofrecen un cambio de percepciones. Todos tenemos la facultad de cambiar estos patrones pero en la mayor parte de los casos, somos incapaces de usar otros que no sean los habituales. Es en esta etapa de percepción, y no en la de procesamiento, donde no cabe el pensamiento lógico. Habrá que utilizar nuevos hábitos de provocación, muchas veces basados en el azar, en el acceso a lo irracional, en juegos deliberados para poder cambiar los patrones establecidos por otros nuevos. Por otra parte,

\footnotetext{
${ }^{1}$ Gregory, 1995: 246.

${ }^{2}$ Ibídem: 246.

${ }^{3}$ Ibídem: 875 .

4 “Suponga que estamos buscando una idea nueva para una marca de cigarrillos. Usamos una de las técnicas más provocativas de pensamiento lateral, y presentamos una palabra al azar como provocación. La palabra se puede elegir de un diccionario mediante una lista de números aleatorios, de modo que no tenga lugar una selección inconsciente.

¿Significa esto que se puede utilizar como provocación una palabra cualquiera con cualquier problema? Sí, esto significa. No hay la más mínima conexión entre la palabra aleatoria y el problema. La palabra es "jabón” y de ella surge la idea de frescura, y de primavera, y de poner semillas de flores en el final de los cigarrillos, para que cuando se tiren las colillas crezca una flor de cada una de ellas y se embellezcan los alrededores en vez de contaminarlos. Es muy difícil imaginar cómo una idea semejante podría surgir sencillamente del análisis de un cigarrillo, ya que no hay nada en él que sugiera este tipo de idea” Ibídem: 876.
} 
el uso de las drogas supone tal alteración de la conciencia que no extraña su participación en una percepción que se sale de los patrones habituales. $Y$ es que los juicios sirven para reforzar los patrones existentes, pero para cambiarlos, es necesario utilizar otras herramientas, herramientas que ayuden a la provocación. Aquí surge el movimiento, el límite, la frontera con la lógica. Aquí surge el pensamiento lateral. Tristán Tzara acertaba al proponer en una receta esta apertura a otros elementos irracionales:

\author{
"Tomad un periódico. \\ Tomad unas tijeras. \\ Elegid en el periódico un artículo que tenga la longitud que queráis dar a vuestro poema. Recortad el artículo. \\ Recortad con todo cuidado cada palabra de las que forman tal artículo y ponedlas todas en un saquito. \\ Agitad dulcemente. \\ Sacad las palabras una detrás de otra colocándolas en el orden en que las habéis sacado. Copiadlas \\ concienzudamente. \\ El poema está hecho. \\ Ya os habéis convertido en un escritor infinitamente original y dotado de una sensibilidad encantadora, aunque, \\ por supuesto, incomprendida por la gente vulgar" 5 .
}

Evidentemente, puede quedar en el lector la sensación de que sólo el azar no puede constituir una obra de arte. Y así es. Estamos hablando solamente de un aspecto creativo, que en fases posteriores puede ser abandonado a favor de una construcción lógica de los textos. Si sólo fuera el azar, a menudo nos encontraríamos creaciones imposibles de percibir, por su exceso de ruido, por su dimensión fragmentada. Sin embargo, lo que sucede aquí es síntoma de la libertad, de la libertad de poder utilizar otros patrones, y cuyos resultados, a través de posteriores procesos críticos y lógicos, podrán ser comunicables al público. Por eso, desde una perspectiva ética, esta fragmentariedad tiene connotaciones positivas. Comparémosla con otra fragmentariedad a través de otro discurso, el televisivo. Doy los datos. Días posteriores al fatídico 11 de marzo, en diversas cadenas generalistas. Imágenes del mismo 11 marzo, por la noche. Un informativo nacional. Al plano de uno de los trenes de cercanías destrozados por las bombas, le sucede un spot publicitario en el que se anuncia un perfume: la imagen, la de una mujer que mira un tren de cercanías, como el que se ha visto destrozado con anterioridad, pero esta vez reluciente y perfecto. Siguiente conjunción. Último plano del informativo: la imagen del muchacho con un ojo destrozado y su camiseta empapada en sangre. El spot inmediato anuncia un detergente e insiste en la ropa limpia. Y el perverso tercer ejemplo: día del Funeral en la Almudena, en Madrid, por las víctimas de los atentados. Último plano del informativo: la entonces reina Doña Sofía llorando. A éste le sucede un spot que comienza con el plano detalle de un ojo, del que sale una lágrima. Se escucha "una furtiva lacrima" operística. Y todo para anunciar "LG, emoción líquida" para las pantallas de cristallíquido en los televisores.

Esta fragmentación no es fruto del azar. Es asociación de ideas, pero no como elemento irracional y libre. Es asociación de ideas, pero perversa asociación. Podemos criticar por qué la ética, y los demás valores que sustentan nuestra sociedad, son aplicables en el movimiento mismo. Esta asociación audiovisual es premeditada. Es útil sospechar. Es útil no ejercer la candidez en la interpretación de los medios. Las asociaciones de ideas que llevan de la tragedia (lo sublime aunque fatídico) al consumo, no nos hace mejores personas, nos emplaza no como ciudadanos, sino como consumidores hasta en la misma tragedia. Capitalismo perverso, creación perversa ${ }^{6}$.

\footnotetext{
${ }^{5}$ En De Micheli, 2002: 269. Estas instrucciones, bajo el epígrafe "Para hacer un poema dadaísta", incluidas en el Manifiesto sobre el amor débil y el amor amargo, fueron escritas en 1920, leídas en la galería Povolozky de París el 12 de diciembre de ese año y publicadas posteriormente en el no 4 de la revista La vie des lettres. Noten, al final de la composición, que lo irracional es aún individual, no colectivo. De algún modo, la imagen de artista separado del resto de los ciudadanos sigue perpetuándose. Por su parte, Marina analiza esta obra y otras en alusión a la dimensión lúdica de las creaciones, y a los elementos de azar que intervienen en ella: "un síntoma del ingenio". En Marina, 1992:138.

${ }^{6}$ No quiero olvidar tampoco, en esta manipulación falta de ética, otras asociaciones que intentaron ser impuestas desde los medios, y que tuvieron mucho que ver con la respuesta electoral del 14 de marzo. El11 de marzo (o tal vez en
} 
Volvamos ahora al entorno creativo, a la génesis de nuevas hipótesis para crear saltos conceptuales verdaderamente creativos. Afortunada o desafortunadamente, en esta época hemos visto que cualquier idea puede argumentarse con las herramientas de la razón. Y esto se demuestra porque somos capaces, a partir de una asociación aportada por el azar, de realizar una argumentación lógica a posteriori que asocie dos ideas ${ }^{7}$. Si estuviéramos entreviendo el problema desde la Programación Neurolingǘstica, diríamos que, en una primera parte, habríamos de conectar con nuestro yo creativo (dispuesto a una especie de brainstorming con pensamiento lateral), pero para continuar asociándonos a un yo crítico y comunicacional, el destinado a hacer de nuestro proyecto creativo algo comunicable.

\section{$¿$ Crear colectiva o individualmente?}

Seguimos en un entorno del cambio, del movimiento, de límite, de fronteras de la razón. Hasta ahora, en el análisis del pensamiento, especialmente del pensamiento lateral, el movimiento ha sido expresado como una nueva percepción no habitual en los patrones perceptivos. Se trata, por tanto, de una perspectiva desde el individuo.

Pero, ¿qué ocurre con las creaciones colectivas? En este caso, nos encontramos en una situación diferente. ¿Cómo interviene esa provocación, esa anécdota que permite crear, pero en este caso entre dos o más personas? Y se plantean otras cuestiones: ¿es una creación colectiva la suma de varias creaciones individuales? Para eso debemos acceder a otros conceptos, el de emergencia y el de reducción. Con la reducción se ponen en práctica nuestras cualidades analíticas. Reducimos elementos para hacerlos explorables. La reducción y la lógica entran en un mismo campo. La emergencia, por el contrario, sería el reverso de la reducción. Porque cuando se combinan ciertas partes, pueden emerger de dicha combinación unas propiedades que serían imposibles de entrever con una operación que intentara analizar los elementos que la componen por reducción. La emergencia tiene, de alguna manera, una cualidad misteriosa. Un ejemplo clásico de emergencia sucede en el elemento más común de nuestro planeta. El líquido agua surge como cualidad emergente, pero precisamente de la combinación de los gases oxígeno y nitrógeno.

Es en la combinación, en el movimiento, donde es precisamente posible intuir esta materia. Las propiedades del agua no están en los gases que la constituyen. Las propiedades de la mente pueden emerger de la estructura o actividad física del cerebro. El funcionamiento de un hormiguero es algo más que la suma de las hormigas. Una vez destruido, son incapaces de reconstruirlo. Es un sistema que funciona por sí mismo, como emergencia. Una neurona es incapaz de comprender, pero sí lo hace la mente emergente de la estructura creada por los millones de neuronas que constituyen nuestro cerebro ${ }^{8}$.

Este tipo de comportamientos revela una naturaleza compleja que se da tanto a nivel individual como colectivo. En el análisis de lo irracional durante el siglo XX es obligatorio referirnos a los avances del psicoanálisis con dos figuras señeras que pueden darnos datos acerca de esa dimensión en el individuo y en la colectividad: Freud y, de nuevo, Jung. A partir de su trabajo en 1900 en Burgholzli, el hospital mental y clínica universitaria psiquiátrica de Zurich, Jung comenzó a desarrollar sus primeros escritos sobre la asociación libre de palabras, materia en la que fue pionero.

la temprana madrugada del 12 de marzo), en Antena 3 Pedro Piqueras comunicaba que se había encontrado la cinta con enseñanzas del Corán junto a unos detonadores en una furgoneta, para terminar, en la misma frase, con esta expresión: “...este ...terrible ...atentado ...de ETA". Si son necesarias las asociaciones de ideas inusuales en la misma percepción para configurar nuevos modelos de patrones y generar ideas auténticamente creativas, para crear nuevos saltos conceptuales, las hipótesis han también de ser nuevas. En el caso de Piqueras nos encontramos con el reverso de esta idea: para continuar con una percepción, se ha intentado eludir una asociación de ideas evidente.

7 "En un sistema de patrones es perfectamente lógico ser ilógico. En el ejemplo citado anteriormente no hay conexión entre el cigarrillo y el jabón, pero se elabora rápidamente una siguiendo alguna de las muchas vías de asociación que poseemos. Nuestras ideas acerca de los cigarrillos pueden ahora comenzar a surgir a lo largo de esta trayectoria, y toman un rumbo diferente del que habrían tomado en otra. Por tanto, la razón para yuxtaponer cigarrillos y jabón solamente aparece después de haber hecho la yuxtaposición y de haber probado su utilidad" En Gregory: 877.

${ }^{8}$ Ibídem: 346. 
"Jung concluyó que, mediante la asociación de palabras, se pueden descubrir constelaciones de ideas, que están cargadas emocionalmente y dan lugar a síntomas mórbidos. La prueba se realizaba valorando al paciente en función del intervalo entre el estímulo y la respuesta, la adecuación de la palabra con que respondía y la conducta que mostraba. Una desviación significativa de lo normal indicaba la presencia de ideas inconscientes cargadas de afecto, y Jung acuñó el término "complejo" para describir esa combinación de la idea y la fuerte emoción que suscitaba"

Se trataba aún de unas investigaciones basadas en sus experiencias clínicas con individuos concretos. Freud, por su parte, se centraría durante toda su vida en el análisis también de individuos, y no tanto de colectividades. En 1907, en Viena, se reúnen Jung y Freud por primera vez. En aquellos iniciales años de colaboración, Jung defendería las teorías freudianas, pero a partir de 1911, comenzaría a alejarse de la explicación sexual aportada con tanta fuerza por su colega. Los vínculos causales que hacían que Freud se retrotrajera a la infancia del paciente revelaban cierta explicación del comportamiento humano basada en el mecanicismo. Pero la perspectiva de Jung se iba acercando a la idea de situar al ser humano en un contexto, en una comunidad. Esa contextualización podía dar "significado y dignidad a su vida y, en último término, suponía un lugar en un universo con sentido" 10 . Pero mientras Freud volvía sobre la infancia y se empeñaba en buscar las causas en un pasado, Jung se interesaba por las crisis que se producían en los individuos en la edad adulta, cuando ya tenían una identidad sexual formada, estaban separados de los padres, eran independientes laboralmente, y a pesar de esto, necesitaban ayuda psicológica. Jung apuntaba a una unificación del individuo en una entidad mayor, como si en nuestro viaje evolutivo tuviéramos una necesidad de trascendencia (y creo que el mismo Jung, al acercarse al I Ching, manifestaba esa necesidad de trascendencia para sí mismo). La integración psíquica, el logro de la totalidad, tenían relación con símbolos arquetípicos. Jung se servía de imágenes provenientes de religiones orientales y occidentales, del mundo de la alquimia y la literatura. La evolución de cada uno de nosotros se revelaba en estas imágenes arquetípicas, imágenes que "se experimentan, a menudo con gran intensidad emocional en sueños y visiones, y que, además de conectar al individuo con el resto de la humanidad, apuntan también a su propio destino peculiar" ${ }^{11}$. Esta dimensión espiritual es paralela en la psicología a otros posicionamientos desde el arte colectivo, como veremos más adelante. Como si se tratara de una cualidad emergente, y también misteriosa, parece que el desarrollo evolutivo del ser humano lo hace converger con una mente o entidad divina, trascendente, unida a todas las cosas. Y se entiende, precisamente, desde la misma evolución del individuo. Tal vez a ello se debiera que Jung terminara sus memorias con esta declaración: "Cuanta mayor incertidumbre he sentido sobre mí mismo, más ha crecido en mí el sentimiento de parentesco con todas las cosas. De hecho, me parece como si esa alienación que durante tanto tiempo me ha separado del mundo se hubiera transferido a mi propio mundo interno y me hubiera revelado un desconocimiento inesperado de mímismo" ${ }^{21}$.

Pues bien, si podemos asociar a Freud con el estudio del individuo, Jung, sin renunciar al individuo, se centra en conceptos que incluyen la idea de un ser inserto en una comunidad. La ampliación de esta comunidad nos lleva finalmente a su concreción en imágenes arquetípicas, como si una unidad mayor, una especie de organismo, emergiera, al ser algo más que la suma de sus componentes individuales. La contrapartida a esto nos llevaría a una suerte de asociación entre el microcosmos y el macrocosmos. A menudo los físicos han puesto en evidencia que los agujeros negros a nivel interestelar son la versión macrocósmica de la antimateria revelada en el conglomerado minúsculo que es el átomo. De alguna manera, esto también afecta a las cuestiones que estoy abordando aquí, pues el desarrollo de la psicología en el siglo XX ha incidido cada vez más en la posibilidad de observar la conciencia del individuo como un conglomerado de conciencias (los diferentes "yoes"). La conciencia unificada, y la misma noción de identidad, se vuelven complejas y se diluyen.

\footnotetext{
${ }^{9}$ Ibídem: 639 .

${ }^{10}$ Ibídem: 640 .

${ }^{11}$ Ibídem.

${ }^{12}$ Ibídem: 641.
} 
También podría argüirse que, según la perspectiva que se tome, podremos estar hablando de individuos o colectividades. Es cuestión del posicionamiento en el discurso. Como si se tratara de estar intentando medir un objeto fractal: necesitamos primero ponernos de acuerdo sobre desde qué perspectiva lo mediremos. Asociar la palabra "inteligencia" (que es una facultad, una puesta en práctica desde un ser individual) al adjetivo "colectivo" implica, sin embargo, ubicarse en una situación en la que admitimos la complejidad de un ser que está compuesto por miembros. Un meta- cerebro en el que tal vez los miembros nunca puedan siquiera imaginarla dimensión de cada una de sus acciones conjuntas. Francis Heylighen, experto en sistemas complejos, afirma que:

"Inteligencia Colectiva es aquella capacidad de grupos de agentes (personas, insectos, robots, programas de computador) de solucionar problemas o de encontrar mejores soluciones que todas aquellas que pudieran ser encontradas por todos los miembros del grupo trabajando individualmente. Bajo esta definición, un ejemplo clásico de inteligencia colectiva es el de los insectos; individualmente no dan muestras de inteligencia pero en la medida en que estos interactúan de acuerdo a reglas claras de grupo, dan la impresión de que todos pudieran enfrentarse a problemas que individuamente no podrían solucionar, por ejemplo: las hormigas cuando desean encontrar y reunir comida en el hormiguero"13.

Pero no se trata solamente de que una serie de agentes interactúen. Para ello, ha de haber un Mapa Mental Colectivo, esa "memoria compartida" que los miembros actualizan y leen. No es extraño pensar, por tanto, que cuando Jung hablaba de un inconsciente colectivo, de algún modo, estaba siendo un visionario de esa inteligencia unificadora y que nos trasciende como miembros de un todo (y lo más seguro es que no seamos conscientes de ella).

La escritura permitió la generación de uno de los mapas mentales colectivos más antiguos. Este mapa mental colectivo permitió el almacenamiento del conocimiento fuera del cerebro de cada individuo. Con la invención de la imprenta, el acceso a gran cantidad de información por cada vez más individuos supuso que nos conformáramos en nuestra ontogénesis particular a través, entre otras cosas, de ese mapa. El mapa mental colectivo pudo ser actualizado por numerosos autores, los que podían publicar. Pero esa posibilidad se limitaba a unos pocos. Hoy en día, gracias a Internet, el mapa mental puede ser actualizado por un número mucho mayor de personas, aunque, de nuevo, se esté estratificando la posibilidad porque el acceso depende en gran medida de nuestros bolsillos y de la residencia en un área más o menos desarrollada del planeta. En suma, las diferencias siguen existiendo, pero el número de agentes que intervienen en ese mapa mental ha aumentado enormemente.

Está claro que la creación es una actividad inteligente. Marina hacía una excelente disertación sobre ello en su libro Teoría de la Inteligencia Creadora. Por otra parte, el desarrollo de la inteligencia en general tiene un componente colectivo ineludible. El macrocosmos se une al microcosmos. Reconocer al otro como otro hace nacer la experiencia del sí mismo. Freud, Piaget o Vigotski incidieron en este hecho desde distintas perspectivas. El proceso de pensamiento humano no es exclusivamente privado, éste se realiza en el transcurso de un diálogo con uno o más interlocutores, reales o imaginarios. La capacidad de pensar se ejerce en función de una implicación en las comunidades vivas con sus herencias, conflictos y proyectos. En primer o en segundo plano estas comunidades están siempre presentes en el menor de los pensamientos de cada persona. Somos, también, circunstancia. Somos resultado de la filogénesis y la ontogénesis. Esta relación entre lo individual y lo colectivo se manifiesta de una manera mucho más impactante desde el momento en que aparecieron las primeras fotografías del globo terráqueo. Si los valores, imágenes y herramientas que se nos transmiten culturalmente tienen una referencia que me incluye, pueden desarrollarse pensamientos individuales que admiten esa globalidad, y que afectan por tanto a la psicología particular. Cuando las herramientas, que son las que incorporan la memoria individual, producen imágenes globales, éstas pasan también a conformarnos. Como en el rap de Drexler: "Hay-manos- capaces-de-fabricar-herramientas-con-las-quese-hacen- máquinas-para-hacer-ordenadores-que-a-su-

\footnotetext{
${ }^{13}$ Padilla Obregón, Francisco: "Inteligencia Colectiva e Inteligencia Conectada”. En: http://www.javeriana. edu.co/Facultades/C_Sociales/Facultad/sociales_virtual/trabajo04.htm. 2002. (Consultado el 06-05-2004).
} 
vez-diseñan-máquinas-que-hacen- herramientas-para-que-las-use-la-mano" ${ }^{14}$ Viendo la fotografía de la Tierra, puedo adquirir un sentimiento de la unidad de nuestro planeta y de la humanidad que la habita.

"Seguramente, los efectos más importantes producidos por la fotografía de la Tierra son de extender la percepción de nuestro yo más allá de nuestra propia imagen corporal, y de ensanchar nuestro sentido de identidad. Ciertamente, desde el primer momento en que vemos esa fotografía, tomamos posesión de la Tierra y de un nuevo poder para intervenir en ella. [...] Gracias a esta fotografía, yo soy la Tierra y también lo es cualquier otra persona. Ésta es una nueva experiencia psicológica con enormes implicaciones. La mejor venganza contra las psicotecnologías que nos transforman en extensiones de ellas mismas consiste en incluirlas dentro de nuestra psicología. Un nuevo ser humano se está formando"15.

Lévy ${ }^{16}$ se plantea también si los grupos humanos pueden mostrar más inteligencia, sensatez, sabiduría o imaginación que las personas que los componen. $Y$ es una cuestión que plantea desde el presente, no como ejercicio histórico acerca de colectividades del pasado. La organización de estas colectividades a partir de formas autoritarias o de burocracias parece en muchos ejemplos haber anulado las potencialidades de los miembros. Y afirma que si bien las reglas han servido para valorar las inteligencias en grupos pequeños, cuando analizamos grupos de más de 10.000 personas, las inevitables gestiones jerarquizadas no han servido para potenciar los valores individuales. Por ello plantea la siguiente hipótesis, acorde con actores políticos, artísticos y económicos: "las técnicas contemporáneas de comunicación podrían redistribuir aquel antiguo reparto antropológico que condenaba a las grandes colectividades a formas de organización política muy alejadas de los colectivos inteligentes"17. Pero mientras los individuos que han ostentado el mundo de la cultura han utilizado normas que hacían viva esa culturaa través de una serie de reglas y valores que enriquecían el patrimonio común, la educación del gusto y el sentido crítico, la estimulación de la innovación y otras cuestiones, este cultivo se restringía a los ámbitos especializados. Apunta, además, que los colectivos inteligentes suelen poner en entredicho el poder. La apertura a cuestiones artísticas globalizadoras y de respeto a la diversidad podría estar aportando notas a un programa en el que todo hombre, como decía Beuys, es unartista:

"El ideal de la inteligencia colectiva evidentemente no es difundir la ciencia y las artes en el conjunto de la sociedad, descalificando al mismo tiempo a otros tipos de conocimiento o de sensibilidad, sino reconocer que la diversidad de las actividades humanas puede y debe ser considerada, tratada y vivida como "cultura" en el sentido que acabamos de evocar. En consecuencia, cada ser humano podría debería- ser respetado como un artista o un investigador en la república de los espíritus"18.

Y resulta muy aclaratorio que distinga entre la potencia debida una colectividad inteligente y la debida a una colectividad dirigida inteligentemente. La primera sería, en este mundo fragmentado, la que responde al fenómeno de la emergencia, mientras que la segunda provendría del análisis, la reducción, y las relaciones impuestas depoder.

Apunta más tarde la necesidad de la aparición de un objeto-vínculo, catalizador de la inteligencia colectiva. Tal vez nunca podamos saber a ciencia cierta cómo funcionan aportaciones (en este caso, artísticas) dentro de un entramado en continuo movimiento y más global. Tal vez, nuestras aportaciones individuales (hayamos utilizado para ellas procesos lógicos o irracionales, o ambos a la vez) pudieran funcionar en una colectividad dirigida inteligentemente como un elemento lógico, pero también podrían funcionar como un acicate irracional y misterioso en el engranaje de movimientos que compone una colectividad inteligente. De todos modos, poco podríamos saber de

\footnotetext{
${ }^{14}$ Canción con letra y música de Jorge Drexler, publicada en su disco Eco, producido por Dro East West. Dice Drexler: "Por primera vez, es un disco en el que la palabra y la emoción prevalecen por encima de todo. Es un álbum centrado en el texto". http://www.cantautoresdelmundo.com/especiales/eco/index. htm (consulta 14-04-2004).

${ }^{15}$ Kerckhove, 1999: 245.

${ }^{16}$ Lévy, 1999: 107.

${ }^{17}$ Ibídem: 108.

${ }^{18}$ Ibídem.
} 


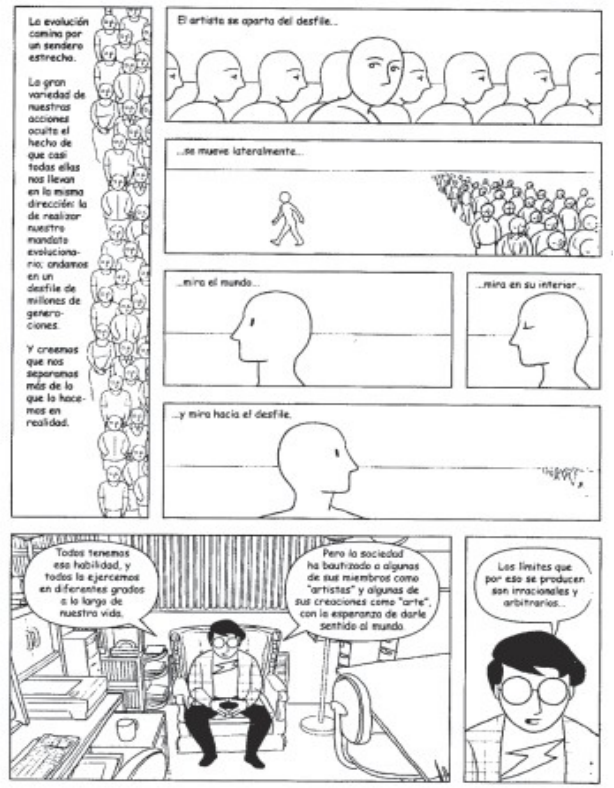

Fig. 1. El artista como ser que sale de la norma social. MCCLOUD, S.: La revolución de los cómics. Biblioteca Creativa no 6. Barcelona: Norma, 2001 pág. 54.

ello, pues supondría vivir desemplazados de nosotros mismos e intuir, como tantas veces le pasó a Jung, una entidad mayor sin ser directores de la misma.

\section{Crear ¿colectivamente? (Los cimientos de las vanguardias)}

Veamos las viñetas de Mccloud de la primera ilustración que exponemos en este texto.

La idea de artista como individuo que se desplaza de la sociedad es algo que se remonta al Renacimiento, momento en que existe la reivindicación del individuo creador frente a los gremios y corporaciones. De un anterior trabajo en grupo extremadamente reglado y jerárquico, se pasa a valorar las inquietudes de un creador individual. Desde entonces, y acentuada aún más la individualidad de un artista con la imagen del creador romántico, no aparece una tendencia al arte colectivo hasta las mismas vanguardias. En ellas se perpetuará en alguna medida la exclusividad de "carácter" del artista creador frente a una masa indiferenciada de personas (el resto de la sociedad), pero también aparecerán nuevos formatos plásticos y una tendencia al arte colectivo que apenas había estado presente en el imaginario de siglos precedentes. Esa apetencia del crear como ideal común, se materializará también en el cruce de fronteras: el chileno Vicente Huidobro en su manifiesto creacionista nos refiere que "la poesía creacionista adquiere proporciones internacionales, pasa a ser la Poesía, y se hace accesible a todos los pueblos y razas, como la pintura, la música o la escultura",19.

Los diversos manifiestos que se suceden a lo largo del siglo XX reclaman en buena medida la creación colectiva para sí. Pero sus motivaciones parecen ser extra-artísticas. En el manifiesto titulado Pour l'Art Moderne (publicado por Maurice Castells, pintor belga, el 8 de julio de 1913) se reclama la creación de un ideal común, la formación de un nuevo estilo gracias al descubrimiento de la "conciencia colectiva". Apenas cuatro años más tarde, Gino Severini se destaca en un texto contra la tendencia "ultra-individual" del arte del pasado, afirmando que la creación de una estética colectiva ofrecerá una universalidad de estilo. En 1917, en Leyde, saldrá el primer número de la revista De Stijl, que contiene un programa en el que se anuncia el deseo de pavimentar el camino para una nueva cultura artística y renunciando a la individualidad a favor de lo colectivo:

"Cuando los artistas de las diversas artes plásticas hayan comprendido que deben hablar un lenguaje universal, ya no se aferrarán a su propia individualidad. Servirán al principio general más allá de una individualidad restrictiva... Y, al servir el principio general, deberán crear ellos solos un estilo orgánico. La divulgación de lo bello necesita de una comunidad espiritual, no

\footnotetext{
${ }^{19}$ Huidobro, Vicente: "El Creacionismo" (manifiesto rescatado de http://www.vicentehuidobro.uchile. $\mathrm{cl} /$ manifiesto1.htm).
} 
social. Sin embargo, una comunidad espiritual no puede nacer sin el sacrificio de una individualidad ambiciosa. Sólo aplicando constantemente este principio se podrá lograr que la nueva estética plástica se revele, como estilo, en todos los objetos, naciendo de nuevas relaciones entre el artista y la sociedad" 20 .

El manifiesto del grupo que aparece un año más tarde distingue:

\begin{abstract}
"Hay una vieja conciencia del tiempo, y hay otra nueva. La primera tiende al individualismo. La nueva tiende hacia lo universal. La batalla del individualismo contra lo universal se revela tanto en la guerra mundial como en el arte de nuestra época. [...] El arte nuevo ha puesto en evidencia el contenido de la nueva conciencia del tiempo: proporciones equilibradas entre lo universal y lo individual [...] Los artistas de hoy, movidos en todo el mundo por la misma conciencia, han participado, en el campo espiritual, en la guerra contra la dominación del individualismo, el capricho. Simpatizan con todos los que combaten espiritual y materialmente por la formación de una Unidad Internacional en la Vida, en el Arte, en la Cultura"21.
\end{abstract}

Este rechazo a la individualidad es común a otros textos artísticos. De nuevo en 1917, el programa de arquitectura de Bruno Taut (en el manifiesto de la Arbeitsrat für Kunst) se tiene presente la necesidad de que aquellas obras creadas colectivamente deben ser anónimas: firmar construcciones es ridículo. Un año más tarde, en Francia, el texto Après le Cubisme, de Ozenfant y Jeanneret, ensalza el orgullo colectivo que demuestran los equipos de obreros de una fábrica moderna: ése debería ser el modelo que los artistas modernos habrían de seguir.

La relación con el mundo de la máquina parece ser en muchos de los textos el punto de partida para poder unificar lenguajes, una vez que se tiene presente la necesidad de unos códigos universales. Los productos realizados con las máquinas de la época responden por lo general a planteamientos ortogonales, que constituye una información sencilla con la que la máquina puede trabajar. No extraña el impulso hacia formas regulares en muchos de los movimientos de las vanguardias. Se trata de una popularización que se basa en la normalización. Este colectivismo era, pues, un colectivismo mecanizado, tendente a una representación "objetiva" de las cosas.

Lo curioso es que paralelamente a esta apariencia de búsqueda de un lenguaje universal, en el que por tanto, el mundo de la lógica parece emerger, se dan hallazgos en el mundo del psicoanálisis, que remite al ser humano a una dimensión irracional. Esta dimensión irracional puede ser un acicate en el meta-objetivo (el para qué) del arte. Surrealismo (resulta ocioso ya decirlo) era, precisamente, superrealismo. Y de las observaciones de los textos se intuye un sentimiento espiritual, unificador, aunque los medios que muchos artistas pretendían utilizar eran precisamente los de la máquina. El grupo Dada en 1919 afirma la voluntad de construir una "Casa Artística del Estado" con un dadaísmo que "sobrepase al individuo y que libere a todos los hombres". La dimensión espiritual del arte planea en cada manifiesto. Ya lo hace Malevich al intentar crear un nuevo lenguaje con el señero Cuadrado negro sobre fondo blanco y su manifiesto suprematista. Otros artistas, como los expresionistas alemanes, intentan llevar a cabo la conciliación entre la exigencia de la necesidad interior y la de encontrar en común una nueva expresión para este nuevo mundo que nos rodea. En el entorno soviético será, no obstante, donde la dimensión espiritual sea totalmente laica y afanada en integrarse con los medios de producción. Primero con el constructivismo, y especialmente en los años veinte con el grupo productivista, los artistas trabajan una separación entre el arte "de antes" y el de "la primera cultura de trabajo organizado" considerado como producto de la cultura colectiva, resultado de una nueva estructura económica. Resulta curiosa la combinación de elementos que se ponen en juego. Se predica con entusiasmo el arte del Constructivismo en el que el ser humano tiene en cuenta no lo que le aleja de los demás, sino lo que tiene en común con ellos. Es una espiritualidad colectivizada, pero no religiosa. Este será uno de los primeros pasos de un camino en el que el ser humano occidental irá progresivamente perdiendo la dimensión aurática de la obra de arte. Y, como defendería más tarde Walter Benjamin, es un hecho que va de la mano a la reproducción técnica de

\footnotetext{
${ }^{20}$ De Micheli: 347-348

${ }^{21}$ Ibídem: 349.
} 
la obra artística 22 . En 1921 los miembros de Stijl publican su tercer manifiesto "Hacia la formación de un mundo nuevo", en el que exigen con fuerza una construcción colectiva, un espíritu internacional, que no se podrá obtener más que luchando contra el "individualismo espiritual y material" que "eran las bases de la vieja Europa"²3.

El 11 de enero de 1923 el manifiesto futurista del arte mecánico decía que la máquina era la nueva divinidad que puede unir a los hombres en la gran religión de lo nuevo. Otra vez más, aparecía la tecnología como rito del alma colectiva. Un nuevo manifiesto de Stijl, publicado en 1924, es significativamente titulado "Hacia una construcción colectiva". El mismo año, en Alemania, el pintor ruso El Lissitzky publica en la revista MERZ, de Kurt Schwitters, su manifiesto NASCI. En él insiste sobre la voluntad colectiva que ya comienza a dirigir la producción internacional de su tiempo. Cada vez, de forma más palpable, se verifica el conflicto ante el culto a la personalidad, el mito del individuo creador y la idea de estilo, hecho que también afectó a la Bauhaus al pretender volver al trabajo manual, y eliminar la distinción entre artesanos y artistas: "Formemos una nueva comunidad de artífices sin la distinción de clases que alza una arrogante barrera entre artesano y artista. Concibamos y creemos juntos el nuevo edificio del futuro que abarcará a la arquitectura, a la escultura y a la pintura en una sola unidad, y que un día será alzado al cielo por las manos de millones de trabajadores, como el símbolo de cristal de una nueva fe" ${ }^{24}$. Y la esperanza de que se trate de un esfuerzo que redundará socialmente también se deduce de la conclusión de la conferencia de Jena en 1924:

\begin{abstract}
"La obra debe crecer cada vez más alta, y, cuando haya llegado su tiempo, tanto mejor. Nosotros tenemos que buscarla todavía. Hemos encontrado alguna de sus partes, pero no su conjunto. Todavía no tenemos esta fuerza final porque el pueblo no está con nosotros. Pero nosotros buscamos un pueblo. Hemos empezado allí, en la Bauhaus, con una comunidad a la que consagramos todo lo que teníamos"25.
\end{abstract}

Paralelamente, las apetencias por lograr la obra de arte total continuaban como había ocurrido en los siglos precedentes. En 1918, el gobierno alemán había puesto a cargo del arquitecto Walter Gropius la dirección y administración de las dos escuelas más importantes de arte en Weimar, la Sächsichen Kunstgewerbeschule y la Sächsischen Hochschule für bildene Kunst. Finalmente, tras la unión de ambas, el 12 de abril de 1919 Gropius fundó la Statliches Bauhaus en Weimar, la escuela de arte más moderna en su tiempo. El instituto, que tenía categoría de escuela superior de arte, se propuso el objetivo de construir la obra de arte total arquitectónica. Se constituirá así un nuevo gremio de artesanos que construirán juntos el edificio del futuro formado por la arquitectura, la escultura y la pintura.

Así que, por un lado, los antecedentes del trabajo artístico colectivo se remontaban a la época premoderna, a la agrupación gremial y era precisamente la catedral (la última obra de arte premoderna) un ejemplo de la unificación del arte y la vida social. El caso de la catedral muestra la integración de todas las artes. Las imágenes escultóricas religiosas se combinaban con obras de talante pictórico (vidrieras, frescos, retablos). La música formaba, a través del órgano, parte de la celebración. La poesía se manifestaba a través de la lectura durante la misa. Todos los estamentos sociales disponían de un espacio propio en la catedral, si bien su ubicación dependía de su rango. Y no se

\footnotetext{
${ }^{22}$ Benjamin, 1973: 15-57. Desde otra perspectiva, podríamos considerar que incluso ciertas formas de aparición de arte en la red, a pesar de un uso evidente de la tecnología, responden a principios auráticos. Por ejemplo, la página personal de un artista o de un museo responde a esa individuación del artista. Se trataría, no obstante, de un arte en red, pero que apenas utiliza las posibilidades radicalmente nuevas que aparecen en este medio. En cambio, las obras que se basan en la interacción, las obras abiertas en continua transformación, llevan a una idea de proceso y por tanto de un enfriamiento del aura. El objeto artístico, aunque virtual, es más moldeable que la obra de arte cerrada, autónoma, que nos ha legado la clasificación tradicional de las Bellas Artes. Y, sin embargo, el net.art obliga a una normalización tecnológica. Éste sería el nuevo punto de partida (tecnológico) para un nuevo arte plástico que incluye la usabilidad. Esta normalización, iniciada de alguna manera por constructivistas y productivistas, será también aprovechada como lenguaje en propuestas de la segunda mitad del siglo XX, como el minimalismo.

${ }^{23}$ De Micheli: $350-351$.

${ }^{24}$ Ibídem: 107.

${ }^{25}$ Ibídem.
} 
trataba sólo de un lugar estructurado jerárquicamente para el pueblo, sino creado colaborativamente por éste. Todos contribuían a su construcción.

La Bauhaus busca también la obra de arte colectiva del pueblo: arte del pueblo y para el pueblo. Volver orgánica la sociedad mecanizada y escindida en piezas supone un pueblo, una comunidad, en la que todos los miembros colaboren en la tarea de construir una nueva vida que no se diferenciará ya del arte. La vivienda, la casa, desaparecerá como refugio de los valores del individuo, como lugar opuesto a otros, pues el ocio dejará de ser lo opuesto al trabajo, lo privado lo opuesto a lo público, y la casa estará en todas partes, será cualquier lugar.

La nueva pedagogía de la Bauhaus, basada en el trabajo en grupo, comunitario, orgánico, produce un cambio fundamental: el trabajo artístico no tiene como fin sólo la invención de una forma, sino la modificación, mediante esa nueva forma, del curso de la vida cotidiana en cuanto abarca a la producción de objetos de uso cotidiano (un jarro, una silla, una casa) e implica así el entorno en el que viven todos los seres humanos.

El estándar es un objeto simplificado y práctico que contiene lo mejor de sus formas anteriores, y que está precedido por una eliminación de los elementos no esenciales, de todo lo arbitrario y superfluo, resultado de un trabajo en equipo. La creación de una forma "objetiva" implica pues el trabajo colectivo e histórico.

Creo que a través de esta somera información estamos ya en condiciones de entrever una serie de características ligadas a estos intentos de creación colectiva que pueden ayudarnos a intuir ciertas dinámicas actuales de la creación. No siempre se habrán dado todas las características en los grupos de las vanguardias que hemos repasado someramente, pero enumerarlas puede hacer accesibles otras reflexiones venideras:

- La idea de crear colectivamente implica a menudo a asunción de que existe una conciencia colectiva.

- Esto reta los artistas a la creación de un "nuevo estilo".

- El estilo habrá de tener cualidades "universales". Los lenguajes universales vienen a menudo normalizados a través del ejemplo de la máquina.

- Crear colectivamente supone un conflicto, enfrentamiento o lucha contra la idea de artista individual y contra el arte institucionalizado.

- La comunidad en la que se forja el arte colectivo tiene dimensión espiritual que requiere el sacrificio de la ambición del individuo creador y constituye bases de una nueva relación entre el artista y la sociedad.

- El artista se une al obrero de la fábrica. Los artistas deben aprender a desligarse de su individualismo como lo hace el obrero dentro de los medios de producción, en aras de un beneficio más global.

- Para trabajar colectivamente, a menudo el artista tiene en cuenta no lo que le aleja de los demás, sino lo que tiene en común con ellos. Este hecho convive con retazos de la ultra-individualidad del artista que necesita su expresión interna.

- A menudo, la puesta en práctica de una estructura de poder dentro un colectivo termina siendo el origen de que el colectivo muera.

- Se pretende que vida, arte y cultura conformen una nueva unidad internacional.

- Lo irracional puede corresponder, en algunas corrientes, a lo espiritual. El azar, como elemento no controlable por el artista, puede ser "aquello espiritual" que subyace al colectivo.

- El trabajo creativo colectivo tiene tintes de activismo político desde los medios artísticos, sea a través de tendencias de izquierda o derecha. El artista no puede quedarse neutral ante tan profundas convulsiones del ser humano y el mundo.

- La obra de arte colectivo y el artista colectivo van perdiendo cierta dimensión aurática y el espectador es invitado a participar, aunque sólo sea en los manifiestos, a formar parte del entramado autor-obra de arte- espectador. Existe, como en épocas precedentes, la apetencia de lograr la obra de arte total.

- En algunas corrientes, el trabajo en equipo es relacionado con la estructura gremial premoderna, pero esta interpretación elimina las jerarquías del gremio y se utiliza como elemento liberador (interpretación, por tanto, ajena a la premodernidad). 
- A menudo se pone en duda la distinción entre lo privado y lo público, entre el ocio y el trabajo.

Lo espiritual se materializa. La materia adquiere dimensión espiritual.

- Se intenta modificarla vida cotidiana a través de la elaboración de objetos, lo que constituye una valoración de la importancia de la microhistoria.

\section{Operaciones cancerígenas sobre la creación artística}

A través de esta rápida ojeada a las vanguardias, somos conscientes de que esas colectividades creativas tuvieron una vida bastante corta. Eso no niega su importancia. Forman parte de la Historia del Arte Universal y ofrecieron claves sin las que tal vez hoy en día ni siquiera nos podríamos plantear otras opciones creativas colectivas. Pero intentemos calcular los obstáculos con los que se encontraron.

No sólo en el siglo XX, también en el siglo XXI, cada vez más, somos conscientes de que el arte es un concepto cultural. Nadie puede decir qué es arte. Más bien tendríamos que recurrir a la tautología "arte es todo aquello que el hombre ha dicho que es arte". Como concepto cultural, se trata de un concepto límite, que halla surazón de seren el puro movimiento. Hemos heredado dela modernidad la constitución de una sustancia en el objeto artístico. De hecho, hoy en día son simultáneas la materialización del arte en un objeto artístico (una escultura, una pintura) y la virtualización de la operación artística en un acontecimiento. Con las vanguardias, se inició el camino de esta operación de virtualización en el sentido de Lévy: la iniciación de una problemática. Y, aunque el libro de Lévy date de 1999, realmente se estaba iniciando esa problemática que nos llevaría luego a categorizaciones intermedias entre realidad y virtualidad. Así, en la actualidad la realidad aumentada incorpora elementos virtuales sobre nuestra experiencia cotidiana, fenomenológica, con los objetos. No sustituye la realidad física, sino que sobreimprime los datos informáticos al mundo real. Un metaverso es un espacio virtual colectivo y compartido con frecuencia, creado por convergencia y compatibilización con un aspecto de la realidad externa. Son solo dos ejemplos de cómo ha ido evolucionando la problemática vaticinada desde Lévy hasta nuestros días. Pero, en el contexto de las vanguardias, esa problemática se actualizaría y se materializaría en objetos artísticos porque existía la intención de realización de objetos, aunque fuera para uso colectivo y su inserción en la vida cotidiana. Si nos fijamos, todo este proceso responde a unos patrones lógicos, relacionados con sistemas de trabajo industrial. Así pues, si se pretendía unir arte y vida, en la mayor parte de los casos se estaba intentando dirigir esta unión por medios racionales. Se trata por tanto del inicio de una inteligencia colectiva creadora, pero con los caminos muy trazados, no emergentes.

Con las vanguardias subsiste aún la idea del artista como compositor de un "mensaje". Los artistas, aun queriéndose asociar al pueblo, han utilizado métodos lógicos que tienen poca vida en una inteligencia colectiva que funciona sistémicamente. La unión arte-vida toma sobre todo elementos de la racionalidad en el trabajo mecanizado de la modernidad industrial. Pero es que aún en este comienzo del siglo XX no se han popularizado ideas tecnológicas complejas. Algún pintor se ve influido por ideas de la geometría no euclidiana. Se pone en práctica el cinetismo (móviles de Man Ray o de Calder). Se plantean las descomposiciones espacio-temporales en las representaciones pictóricas cubistas. Pero, una vez que el eco de la onda está comprendido, se estabiliza, se convierte en partícula. Lo posible termina convirtiéndose en objeto real.

El artista sigue creando mensajes desde la individualidad. Los manifiestos intentan plantear una exclusión. Cortan con lo anterior. Plantean un conflicto. Por otra parte, la tecnología de la época es limitada. Demos por tanto ahora un salto en el tiempo para encontrar algún colectivo que comparta presupuestos de las vanguardias, pero que sea contemporáneo a otras tecnologías más desarrolladas. GRAV, el Groupe de Recherche d'Art Visuel trabajó activamente desde los presupuestos de la colectividad en París, de 1960 a $1968^{26}$.

Sus obras se inscriben en la tendencia de desarrollar las posibilidades plásticas de un arte programático que, en 1961, llevaba a Umberto Eco a elaborar su concepto de obra de arte abierta. Como su nombre indica, el GRAV (Grupo de Investigación de Arte Visual) hace hincapié sobre todo en la investigación. Por una parte, pretende establecer normas fijas, por otra parte, también aspira a

\footnotetext{
${ }^{26}$ Once artistas firmaron el manifiesto original, pero solamente seis de ellos formaron la base del grupo: Horacio García Rossi, Francisco Sobrino, François Morellet, Julio Le Parc, Joël Stein y Jean-Pierre Vasarely, conocido como Yvaral.
} 
extender lo visual y a darle un sentido interactivo. Este sentido interactivo representa un más allá en el arte colectivo, pues no se inserta solamente en la cooperación desde la creación, sino en la participación de aquéllos que no son contemplados como artistas, los espectadores. De alguna manera, GRAV sigue la creencia (apoyada por el pintor del arte óptico Víctor Vasarely, padre de Yvaral) de que el concepto de artista como genio solitario se había quedado anticuado. El objetivo principal del grupo fue fusionar las identidades individuales de los miembros en una actividad colectiva que sería "más que la suma de las partes". También pensaban: "los que trabajen colaborando con la ayuda de las disciplinas científica y técnica serán los únicos verdaderos creadores del futuro". Se perpetúa por tanto, la idea de emergencia y por otro la tendencia de unión con la tecnología.

El grupo expuso en Europa en el marco del movimiento de la NOUVELLE TENDANCE, y desarrolló con éxito la lógica de la actividad grupal a través de la estrategia del anonimato y el desarrollo de acontecimientos colectivos llamados "Laberintos". Desde el principio, los miembros de GRAV adoptaron el principio de someter el trabajo individual a la consideración del grupo en su totalidad, que determinaría su importancia dentro del programa total.

En 1961 se sentían bastante seguros como para afirmar que la "realidad plástica" era inherente a "la relación constante entre el objeto plástico y el ojo humano". Esta convicción los condujo a experimentar con una amplia gama de efectos cinéticos y ópticos, empleando varios tipos de luz artificial y de movimiento mecánico así como movimiento óptico o "virtual".

En Assez de mystifications!, (jbasta de mistificaciones!) el texto que publicaron con ocasión de la Biennale de Paris en 1961, el grupo expone su idea de "obra abierta, pero con todo precisa y querida", que se concretará después en una serie de instalaciones colectivas, destinadas a sacar al espectador de su actitud contemplativa para incitarlo a la participación activa. No es casualidad que el GRAV utilice las posibilidades que ofrece la interactividad lúdica que facilita el acceso al público, manteniendo al mismo tiempo la distancia necesaria entre la obra y el espectador, para no correr el riesgo de desaparecer en una indiferencia estética. La ampliación del concepto del arte con el objetivo de permitir una participación activa como la que se experimenta en los laberintos y los espacios lúdicos, se revela como una estrategia extremadamente eficaz, capaz de minar el marco fijado por las instancias del arte, y ya contiene la exigencia de una mayor participación en las estructuras sociales y políticas que desembocará en el mayo de 1968. Estos laberintos son, además, representaciones metafóricas de caminos intrincados, de propuestas complejas, que se plasman bidimensionalmente para que el espectador pueda recorrerlas. Unos años más tarde la www planteará un laberinto multidimensional y virtual (aunque pragmático).

A finales de los sesenta y principios de los setenta asistimos también a las propuestas del arte conceptual, un arte que pone sobre la mesa la idea de desmaterialización. Art as Idea as Idea, escribía Kosuth, intentando asimilar al arte con una proposición analítica kantiana. El rechazo a la mercantilización del objeto artístico hacía poner el énfasis en el arte como operación intelectual, sin referencia con el exterior. A menudo, los "restos materiales" (un anuncio en un periódico, un legajo de folios mecanografiados, una plasmación fotográfica) no eran más que "documentos" porque, precisamente, el arte era la idea, lo inaprehensible. La herencia de Duchamp y su ready-made como operación mental era innegable. El colectivo Art and Language se empeñaba en dejar "huellas materiales" que podían hacer intuir en el espectador esa concepción del arte como idea. Sin embargo, con la distancia que hemos adquirido en este siglo XXI, sabemos que aquellos documentos de la época, con apariencia aséptica, han sido también mercantilizados como objetos culturales. Los nombres de los artistas de este colectivo son ahora productores de objetos materiales que se venden por sumas millonarias.

Tanto los objetos artísticos creados por las vanguardias como los propuestos como documentos (conceptual) o puestos en escena interactivamente con el espectador (GRAV) parecen ser el punto final de un proceso creativo. Después de ello, el capitalismo ha dotado a estos objetos de un valor económico. Por mucho intento de hacer trabajar a una colectividad para un bien común, el objeto termina siendo un objeto de pertenencia. El dueño de unos folios de Art and Language los vende a un precio superior a un segundo comprador. En los Museos, Centros de Arte Contemporáneo, (esos osarios de objetos que son frutos de un proceso), esos documentos son sólo una mercancía cultural. Analicemos, por tanto, por qué no parecen ser ya parte de un dinamismo generado dentro de una inteligencia creadora colectiva viva. 
Lévy dice que el objeto mediador de una inteligencia colectiva es un objeto antropológico, un objetovínculo. Es:

\begin{abstract}
"el mismo para todos, pero al mismo tiempo diferente para cada cual en el sentido en que cada uno está, con respecto a sí mismo, en una posición diferente. El objeto marca o traza las relaciones mantenidas por los individuos, los unos respecto a los otros. Circula, física o metafóricamente, entre los miembros del grupo. Se encuentra, simultánea o alternativamente, en las manos de todos. Por eso, cada uno puede inscribir en él su acción, su contribución, su impulso, su energía. El objeto no sólo permite llevar el todo frente al individuo, sino también implica al individuo en el todo. Sin embargo, el objeto, contenido y dominado por los grupos que constituye, continúa siendo exterior, "objetivo", ya que no pertenece al grupo como otro sujeto"27.
\end{abstract}

Muchas obras, tanto de GRAV como de otros artistas, gracias a la interactividad con el espectador, parecen acercarse a esta idea de objeto-vínculo. Esta participación permite un movimiento, un proceso, en el que el énfasis no se encuentraya en un objeto artístico materialmente cerrado.

Tal vez la instauración de lo material, y la de una sola actualización trascendida socialmente, dé lugar a lo que se ha entendido como objeto artístico desde los presupuestos de la modernidad, pero con ello nos apartamos de las posibilidades que ofrece una inteligencia colectiva. También los colectivos creadores examinados hasta ahora en este texto no han tenido más continuidad debido a la adopción del trinomio artista-obra artísticaespectador, como tres momentos diferenciados, pero el énfasis no se ha puesto en las relaciones que provocan. Muchos colectivos de las vanguardias se disolvieron ante la incompatibilidad en la "dirección" de esa inteligencia colectiva dirigida. La centralización de esa inteligencia sería algo así como ver en el cerebro una zona directora de las demás partes, no como una entidad modular y multifuncional. Por supuesto, han existido inteligencias colectivas jerarquizadas y supervivientes (por ejemplo, la Iglesia), pero la actividad dentro de lo llamado eclesiástico a veces se ha impuesto a través de la exclusión de valores de sus miembros individuales.

Dice Lévy que la Historia de la Humanidad podría reducirse a la sucesión de apariciones de objetos. Veríamos "entonces que todo nuevo tipo de objeto induce un estilo particular de inteligencia colectiva y que todo cambio social consecuente implica una invención de objetos. En la duración antropológica, los colectivos y sus objetos se crean a partir del mismo movimiento" 28 .

Pero entre los sesenta y los setenta, si bien los avances tecnológicos con respecto a las vanguardias eran evidentes, un comportamiento capitalista se había agudizado. El objeto-vínculo de Lévy podía estar latente, pero era rápidamente mercantilizado en un objeto-mercancía. La inteligencia colectiva que manejaba el objetomercancía está inscrita en una inteligencia económica. Las intenciones primigenias de los artistas que acentuaban la labor procesual se habían fosilizado para formar parte de una inteligencia capitalista globalizadora.

La expresión "artistas intentando amarrar su papel en el colectivo" implica "colectivo que se diluye". "Intento de amarrar el objeto-vínculo mediador del colectivo creador" implica "objeto vínculo hecho mercancía" (y, por tanto, otra cosa, otro objeto vínculo diferente en una dinámica capitalista).

Las vanguardias, con sus manifiestos, se ubicaron en una polaridad, en una dinámica de conflicto, a fin de obtener un cambio, una mutación. Pero Lévy, cuando habla del artista en una inteligencia colectiva, aporta como condición la no-exclusión de lo otro, hacerlo partícipe. Yo creo que esta exclusión no proviene sólo de los creadores de las vanguardias. Esos artistas eran hijos de la sociedad y la época que los vio nacer. El mismo sistema capitalista genera un rechazo, necesario para su continuidad. El rechazo que hace que ciertos individuos generen nuevas ideas que se enfrentan a un sistema es finalmente aglutinado por el sistema. De ahíque el inicial objeto-vínculo se estabilice en un objeto-mercancía. Y ello conlleva la desaparición de la dinámica que instituye a la inteligencia colectiva creadora para alimentar una inteligencia colectiva mercantilista. Por tanto, habría que plantearse si esta lucha, este conflicto, resulta operativo. Todas las vanguardias han tenido el expreso deseo de cambiar un estado anterior, y que esto es síntoma de la propia evolución de nuestra

\footnotetext{
${ }^{27}$ Lévy: 116.

${ }^{28}$ Ibídem: 117.
} 
sociedad occidental. Luchar es ya un posicionamiento. Me emplazo ante un sistema. Elaboro discursos para romper con lo anterior. Y creo que este es el momento de reflexionar sobre un aspecto importante del capitalismo tardío en el que nos vemos inmersos. Hasta ahora, este liberalismo extremo ha sido capaz de aglutinar todo aquello que se oponía al sistema. De hecho, la misma lucha, el conflicto, que unos cuantos artistas pretenden llevar a cabo, termina de ser tal cuando el sistema capitalista coloca esa reivindicación al nivel de producto. Hace unos años, El Corte Inglés, utilizaba como slogan esta expresión: "Hippy Total". No tengo ni que comentar qué pensarían aquellos jóvenes de los sesenta y setenta cuando vieran convertido en vestuarios y complementos su estilo de vida y sus reivindicaciones. Los mismos artistas contemporáneos al inicio del arte conceptual, que intentaban hacer obras cada vez menos materiales, son hoy en día nombres señeros en el mercado del arte, que ha conseguido vender hasta la antimateria (Yves Klein, Manzoni, Robert Barry). Por eso es lógico plantearse si es efectivo el talante de lucha en un colectivo. Una vez pasada la actuación colectiva, se crean estilos que siempre podrán reportar beneficios económicos. Porque vivimos en una sociedad económica, no política. Todo discurso se convierte en producto. Y este comportamiento es el que refleja la estructura cancerígena del capitalismo. Es el capitalismo el que genera el rechazo, y es el capitalismo el que lo aglutina como parte de sí mismo.

¿A qué me refiero cuando hablo del comportamiento cancerígeno del capitalismo? ¿Por qué asociar capitalismo con enfermedad? Vivimos una época de cambios acelerados, como han manifestado innumerables teóricos como Virilio o Baudrillard. Nuestra forma de vida, nuestras relaciones, mutan, entre otras cosas, en función de los nuevos sistemas de comunicación. El vuelco electoral del $14 \mathrm{M}$ en España se debió en gran parte al paralelismo de información de unos medios de comunicación centrados y otros difusos. El móvil e internet superaron en efectividad a los tradicionales medios de comunicación de masas. El contacto persona a persona a través de las nuevas tecnologías se ha convertido en una fuente de ingresos muy lucrativa, que beneficia a las grandes multinacionales. La información, todo tipo de información, crece y se disemina con rapidez. La palabra cáncer, por su parte, designa a un grupo de enfermedades en las cuales las células crecen y se diseminan libremente por el cuerpo. Puede surgir en casi cualquier parte de nuestro organismo: en las superficies externas e internas del cuerpo (carcinoma), en los teijdos que sostienen el cuerpo, como huesos, cartílagos, músculos o grasa (sarcoma), en los ganglios y tejidos del sistema inmune del cuerpo (linfomas), en la médula ósea y el torrente sanguíneo (leucemias). Todos ellos, no obstante, tienen en común el descontrol en el crecimiento normal de las células. En nuestro proceso celular normal de crecimiento se mantiene un balance entre el crecimiento de células nuevas y la muerte de las viejas. Con el cáncer, este equilibrio se pierde. Unas células crecen descontroladamente; otras (o las mismas) se niegan a morir, a suicidarse. En un sistema normal, las células viejas o dañadas se autodestruyen, fenómeno denominado apoptosis. En este sistema capitalista, muchos elementos dañados se niegan a perder el poder, se niegan a morir, aunque vayan sembrando la destrucción allá donde vayan. El poder siempre ha querido sobrevivir. Así que, una vez generado el cambio, se pretende instaurar ese cambio como definitivo, y extenderlo. He ahí el error del sistema ${ }^{29}$, o más bien, lo que nos estállevando a otro sistema. En la extensión del sistema

29 "Para ilustrar lo que significa el control del crecimiento normal, considere la capa exterior de la piel. La delgada capa exterior de la piel normal, llamada epidermis, tiene un espesor de aproximadamente una docena de células. Las células ubicadas en la capa inferior de la epidermis, llamada capa basal, se dividen justo a tiempo para reemplazar a las células que continuamente se desprenden de la superficie de la piel. Cada vez que una de estas células basales se divide, se producen dos células. Una permanece en la capa basal y retiene la capacidad para dividirse y la otra emigra fuera de la capa basal y pierde la capacidad para dividirse. Así pues, el número de células con la capacidad para dividirse en la capa basal se mantiene igual".

"El balance normal entre la división celular y la pérdida de las células se descontrola durante el desarrollo de cáncer de la piel. Para reemplazar las células que se desprendieron de la superficie de la piel, las células basales empiezan a dividirse más rápido de lo necesario. Cada vez que una de estas células basales se divide, las dos células nuevas formadas, regularmente mantienen la capacidad para dividirse, lo que lleva a un aumento total de las células que se dividen"

"Este aumento gradual en el número de células con capacidad para dividirse crea una masa creciente de tejido que se conoce como "tumor" o "neoplasma". El tumor crecerá rápidamente de tamaño si la división de las células es relativamente rápida y no hay señales "suicidas" que provoquen la muerte de las células. Si las células se dividen más 
capitalista tardío, claramente podemos continuar con la metáfora del cáncer. Cuando un imperio quiere extenderse, es lógico comenzar por el territorio vecino. La invasión puede ser de rango cultural. Una serie de productos americanos son ya globales. Las multinacionales extienden sus productos. También hacen que se elaboren en zonas deprimidas del planeta, y sus productos llegan a todo el globo. Pues bien, el cáncer tiene dos mecanismos para diseminarse por el cuerpo: la invasión y la metástasis. En el primer caso las células dañadas migran y penetran en los tejidos vecinos. En la metástasis, las células cancerosas penetran en los vasos sanguíneos y linfáticos, circulan por el torrente sanguíneo e invaden el tejido normal de otras partes del cuerpo. La facilidad de transporte y de las comunicaciones en el siglo XXI hace posible una metástasis desde Norteamérica a otras zonas del planeta. Michael Moore hablaba de una teoría del miedo para explicar el terror del hombre blanco anglosajón a lo diferente. El principio de la agresión está basado en el miedo. La resistencia a morir como cultura implica la muerte de lo ajeno.

En el siglo actual, el "interés" por la multiculturalidad se extendía a grandes eventos como el Fórum de Barcelona, que no obstante está patrocinado por empresas que necesitan lavar su imagen ante sus actuaciones en el llamado Tercer Mundo. En este caso, de nuevo, aquello que es diferente al capitalismo tardío, se convierte en un producto vendible ${ }^{30}$. El conflicto se resuelve transformando al otro en producto. El movimiento antifórum 2004 ponía el dedo en la llaga. Las entidades socias y patrocinadoras suscribían la Agenda de Principios y Valores enlaque sebasaba elFórum ${ }^{31}$, peroasu

lentamente, el crecimiento del tumor será más lento. Sin importar la rapidez del crecimiento, los tumores crecen en tamaño porque las nuevas células se producen en cantidades mayores de lo que es necesario. La formación normal del tejido se alterará gradualmente, entre más y más se acumulen las células que se dividen".(http://press2.nci.nih.gov/sciencebehind/cancersp/cancersp08.htm) (14-04-2004).

30 "El evento va a ser una apoteosis de 'las culturas' como tema para la demagogia política y para la trivialización mediática, una diversión en que la pluralidad cultural se verá reducida a una pura parodia destinada al consumo de masas y a la buena conciencia institucional. Un circo en que la diversidad humana será exhibida como un grandioso y amable show de luz y de color" (El artículo "El gran circo de las culturas", de Manuel Delgado, profesor de Antropología de la Universidad de Barcelona, sobre el Fórum 2004, fue publicado en el periódico El País el 11-09-2002. Fragmento tomado de http://barcelona. indymedia.org/front.php3?article_id=26445 (14-04-2004)).

${ }^{31}$ Estos son los principios y valores del Forum Universal de las Culturas, suscritos por las empresas criticadas desde las tendencias antifórum:

Valores democráticos: El respeto por los valores e instituciones democráticas, con especial énfasis en la promoción de la participación cívica.

Derechos y libertades individuales: El fomento de las condiciones de paz a través de la defensa de los derechos y libertades individuales, muy especialmente en el ámbito de la cultura, con especial atención a los más vulnerables y a la defensa de los principios de equidad y solidaridad, así como al ejercicio del derecho a la información y la participación responsable de los individuos en la construcción de su propio futuro.

Respeto por todas las etnias: El respeto por todas y cada una de las etnias existentes, con especial hincapié en la protección de las minoritarias, y el fomento de la lucha contra toda clase de exclusión.

Respeto por las identidades culturales: El respeto por todas y cada una de las identidades culturales, con especial énfasis en la protección de las culturas minoritarias, en el marco de la consolidación de un modelo de sociedad abierta y plural.

Fomento del diálogo interreligioso: El respeto por todas las religiones y la promoción del diálogo interreligioso.

Reconocimiento de la diversidad lingü.stica: El reconocimiento y el respeto por todas y cada una de las lenguas del mundo, con especial atención a la diversidad lingü.stica entendida como patrimonio universal que es preciso proteger y fomentar, sin perjuicio del aprendizaje de las lenguas comunes y de otras grandes lenguas vehiculares.

Fomento de la creatividad: El fomento de la creatividad, la educación y la democratización del conocimiento como vías de transmisión de valores y actitudes que contribuyen a crear una cultura de paz y a desarrollar el diálogo entre culturas, potenciando los diversos sectores culturales que estimulan la creatividad de los individuos y grupos culturales, y contribuyen a la transmisión y conservación del patrimonio cultural material e inmaterial.

Defensa de la biodiversidad: La defensa de la biodiversidad mediante la protección y mejora de la calidad del medio ambiente, así como la conservación y el uso racional de los recursos naturales.

Responsabilidad social: La necesidad de contar con un tejido económico, social e institucional socialmente responsable, comprometido con un crecimiento económico equilibrado y ecológicamente sostenible.

Desarrollo sostenible: La atención especial al desarrollo sostenible del territorio urbano desde el punto de vista medioambiental, social, cultural y económico, sin perder de vista que la ciudad es el principal hábitat del ser humano del siglo XXI, y el espacio donde se cristalizan sus expresiones creativas y los frutos de la innovación tecnológica. 
vez algunas de estas empresas "financiaban actos de guerra y la explotación social en el mundo (entre ellas Telefónica, El Corte Inglés y Agbar — Aguas Barcelona_ propietaria de Aguas Andina)"

"Las críticas no excluyen tampoco al tercer eje: 'el desarrollo sostenible'. Y nuevamente se apunta a las empresas que apoyan la mega actividad y al gobierno español. Endesa, la cuarta empresa europea con responsabilidad en el cambio climático y — demás esta decirlo— acusada de la destrucción del ecosistema del Alto Bío Bío y del pueblo pehuenche. Hay otras del rubro alimenticio — como Nestlé y Colacaodenunciadas por daño al medio ambiente y uso intensivo de transgénicos como materia prima. Y el gobierno español, cuestionado permanentemente por su negligencia frente al tema del petrolero Prestige, entre otros" 33

Estamos, por tanto, en un estado de la enfermedad en el que ya los síntomas son evidentes. La prevención parece no servir de mucho, pues ha habido mucho tiempo para que la enfermedad se desarrolle. Indefectiblemente, estamos cambiando hacia otro sistema, otro paradigma. Y ¿qué papel juega la creación en el mismo? Desde el camino del trabajo en grupo, parece que va cambiando el papel del artista, aquella célula especializada como visionaria en la sociedad. La gran cantidad de labores creativas se han extendido a lo largo del siglo XX a un mayor número de ciudadanos. Los formatos tecnológicos han ampliado no sólo el poder de creación, sino también de distribución de obras personales y se han multiplicado los contactos entre artistas a través la red. El artista encumbrado puede estar integrado en el sistema predominante, acceder a circuitos de fundaciones, galerías, museos y ferias de arte, pero un buen número de producciones se distribuyen en la red y son de libre acceso (teniendo en cuenta que este libre acceso es relativo). Lógicamente, el artista encumbrado se halla en una esfera de poder. Pero muchos otros artistas se encuentran fuera de una organización mercantil. No obstante, el mismo sistema intenta hacer de ellos y de su proceso creativo, un mero producto.

Así, los Centros de Arte Contemporáneo se han preocupado de disponer de un departamento de audiovisuales o de multimedia, aunque cualquiera pueda acceder a estos materiales desde una

Código de conducta:

Acontecimiento multicultural: Crear un acontecimiento multicultural, en el que puedan participar la mayor parte de las culturas existentes, con especial énfasis en las minoritarias, como expresión del patrimonio cultural de la humanidad.

Acontecimiento plurilingüe: Crear un acontecimiento multilingüe que favorezca el acceso de todos a sus contenidos gracias a la superación de las barreras idiomáticas. Para ello, se pondrán al servicio de la comunicación todos los avances tecnológicos disponibles.

Atención a los colectivos más vulnerables: Prestar especial interés, durante las actividades de preparación y ejecución del Fórum, a la inclusión de los grupos y colectivos más vulnerables. No se escatimarán esfuerzo con tal de hacer posible la participación activa de los colectivos que no puedan asistir al Fórum, ya sea por dificultades económicas o de privación de los derechos humanos, sobre todo civiles y políticos. Criterios de sostenibilidad: Aplicar los principios de sostenibilidad a todas sus actividades de diseño, organización y ejecución.

Desarrollo intelectual: Buscar un desarrollo intelectual y pragmático de los temas tratados y, simultáneamente, acercar los conceptos y principios fundamentales al gran público a través de:

La creatividad aplicada a la forma y el fondo de los temas tratados.

- Un enfoque multidisciplinario: tratar los temas desde distintas perspectivas a fin de hacerlos más comprensibles y poner de relieve las interrelaciones que los unen.

- El uso de las nuevas tecnologías para llegar mejor a un público más amplio.

Nuevas alianzas entre sectores diversos: Promover nuevas alianzas entre sectores diversos (administraciones públicas, empresas y $\mathrm{ONG}$ ) para hacer frente a retos comunes y complejos, como la conservación del medio ambiente, la construcción de la paz o el diálogo intercultural. Conviene dar prioridad a todas aquellas iniciativas que sean fruto de un esfuerzo de colaboración entre distintos sectores, y muy especialmente de los actores del Fórum. Compromiso ético, social y medioambiental: Todas las instituciones colaboradoras del Fórum deben suscribir una declaración de principios éticos, sociales y medioambientales sobre la base de alguno de los modelos internacionales vigentes. (http://www.barcelona2004.org/esp/quees/agenda.htm) (1404-2004).

${ }^{32}$ Núñez, Andrea "Fórum Universal de las Culturas 2004. Barcelona: La fiesta continúa”. En El periodista. La voz atrevida. Año 3, n 49, Domingo 23 de Noviembre de 2003. http://www.elperiodista.cl/newtenberg/1529/ article- 55995.html (0605-2004)

${ }^{33}$ Ibídem. 
conexión en casa. Curiosamente, se utiliza el pretexto de que el papel del museo ante estas obras es el de conservación ante los cambios constantes de software.

La conclusión es clara: vivimos pura metástasis. Se están generando otros tipos de dinámicas que crean un nuevo sistema, pero aún pervive el sistema anterior. El trabajo a partir de una inteligencia colectiva abierta y creadora ahora parece tener más futuro. El artista funciona como un norte. Pone en juego objetos-vínculo que sólo lo serán en la acción colectiva.

"Numerosas investigaciones estéticas contemporáneas recuperan las prácticas arcaicas consistentes en dar una consistencia, en prestar una voz a la creatividad cósmica. Entonces, para el artista, no se trata tanto de interpretar el mundo como de permitir que procesos biológicos actuales o hipotéticos, estructuras matemáticas, dinámicas sociales o colectivas tomen directamente la palabra. El arte, aquí, ya no consiste en componer un "mensaje", sino en maquinar un dispositivo que permita a la parte todavía muda de la creatividad cósmica hacer oír su propio canto. Aparece un nuevo tipo de artista que ya no cuenta ninguna historia. Es un arquitecto del ámbito de los acontecimientos, un ingeniero de mundos para miles de millones de historias venideras. Esculpe directamente sobre lo virtual” ${ }^{34}$.

También se entiende así que el camino a la virtualización, y no a la actualización, sea una vía de una inteligencia colectiva creadora que responda a la inquietud trascendente del ser humano. Por eso "el arte y, por lo tanto, la Filosofía, la política y la técnica que inspira y atraviesa, debe oponer una virtualización revalorizante, incluyente y hospitalaria a la virtualización pervertida que excluye y descalifica" ${ }^{95}$. No se trata ya de luchar contra el cáncer, de vivenciarlo como conflicto, de extirpar un tumor como si no se tratara de nuestro propio cuerpo en metástasis, de un conjunto de células que se resisten a suicidarse aunque estén dañadas. Podemos aprender a vivir con estas mutaciones en nuestro organismo que, indudablemente lo están haciendo ser algo diferente a lo que era. La solución no es ya materializar un objeto-vínculo para luego convertirlo en objeto-mercancía. Tal vez en la mutación se halle el germen del aprendizaje.

\section{Crear en la sociedad del cansancio}

Bajo el título de Objetos desobedientes, entre 2014 y 2015, el Victoria and Albert Museum exhibe en Londres una serie de objetos y acciones que dan lugar a la tercera fase de este artículo. Me resulta curioso que objetos utilizados en la lucha social anticapitalista de todo el planeta sean albergados en un museo definido como de arte y diseño que muestra tantos objetos de la vida de los poderosos (y además lo deja claro en su discurso museístico). En el 2006 investigué ciertas actividades artísticas en el Plantón mejicano, y constaté que si bien aquella lucha social de 42 días ocupando el distrito federal generó objetos y acciones artísticas, y la participación de buen número de artistas, en cambio los galeristas, cargos de museos u otras instituciones del arte asociadas al poder no habían participado en absoluto ${ }^{36}$. Me pareció claro que el significado de la palabra arte tenía una materialización muy diferente si se tenía en cuenta el para qué de la realización de obras artísticas (por su posicionamiento ante el poder establecido). Por otra parte, paralelo al boom inmobiliario en España, numerosos artistas hacían su agosto antes de la crisis, pues más construcciones significaban más metros lineales donde, por ejemplo, ubicar cuadros. Por supuesto, no han sido estos artistas los protagonistas en la lucha contra los desahucios. El arte siempre ha estado asociado al poder, al poder establecido, como refuerzo e imagen del mismo, pero no tanto al poder de la transformación, que es el que me parece más interesante en estos momentos, y es el que vi reencarnado en la exposición Objetos desobedientes.

Vivimos una época convulsa. El filósofo coreano Byung Chul Han hace descansar la sociedad del rendimiento, que ya no disciplinaria, en la exageración de los elementos narcisistas. En La sociedad del cansancio Byung Chul Han se refiere a un paradigma que supera la sociedad disciplinaria, inmunológica y viral descrita por Foucault (y en la que en mi opinión actuaban en conflicto las

\footnotetext{
${ }^{34}$ Lévy: 132.

35 Ibídem: 133-134.

36 Rodríguez, 2007: 146-166.
} 
vanguardias artísticas). El neoliberalismo consigue la máxima producción cuando no somos explotados por "lo otro", sino por nosotros mismos. La sociedad descrita por Byung Chul Han contiene la violencia de la positividad, del supercrecimiento, del superrendimiento, de la hiperinformación, la hipercomunicación, donde no existe la sustracción, donde no es necesario anular lo otro como planteaban las vanguardias del siglo XX, cuando la Historia era aún Historia. Ahora bien, en la sociedad que vivimos actualmente, la repulsión ante el exceso de positividad, de producción, no conduce a la resistencia inmunológica, sino que se convierte en la "abreacción digestivo neuronal y en un rechazo" ${ }^{37}$. En mi opinión, no extraña ver estos niveles de superproducción, engarzándolos con los discursos artísticos, como resultado de la frase de Beuys de "todo ser humano es un artista". Ya los considerados artistas no son sólo los productores, sino que lo somos todos los seres humanos a nivel global, y formamos parte de los discursos de transformación. En este sentido, a partir del análisis comunicacional de este principio de siglo, la aportación de lo artístico tiene que ver con una concepción del arte no asociada al poder (incluido el poder de conservar unos objetos y otros no) sino que la única visión del arte que nos hará pensar globalmente es sentirla como una de las dimensiones humanas, que no es para nada la del mercado y más la que fundamenta el hecho de que se requieran actividades artísticas para el desarrollo humano (por lo que lo artístico forma parte de nuestro sistema educativo). Como, según Han, la violencia de la positividad (que supera a la viral) no es privativa, sino saturativa ${ }^{38}$, esta violencia es inaccesible a una percepción inmediata. La metáfora de la rana hervida podría dar la clave de este tipo de violencia ${ }^{39}$.

¿Y cómo se definir el arte en esa sociedad del cansancio? ¿De qué hablamos cuando hablamos de arte, si éste tiene que ver con la sociedad que usa su nombre, si se trata de un concepto límite? ¿Qué debe ser el arte en esa sociedad del cansancio, que provoca enfermedades que provienen de la saturación, como el síndrome del burn-out, el Trastorno por Déficit de Atención e Hiperactividad o el Síndrome de Desgaste Ocupacional? ¿Es el culto a los objetos de arte, su utilización como mercancía, lo que define al arte? Los museos se hacen espectáculo y se produce una peregrinación de turistas por los grandes museos del planeta.

Hace una década, no éramos conscientes de esa saturación. Con Internet pudimos empezar a percibir obras en proceso de mutación constante, verdaderos objetos-vínculo que se ejercitaban y mediaban en una inteligencia colectiva creativa no dirigida. Muchos proyectos de obras colectivas en Internet estaban basados, evidentemente, en un planteamiento por parte de uno o varios artistas, pero no se trataba de una dirección como pudo verse en el ocaso de muchos colectivos del siglo XX. El creador del proyecto tampoco era un gurú. Había sacado un balón al terreno de juego ${ }^{40}$, pero nunca sabría cómo se iba a desarrollar el partido. Habría que aceptar una serie de reglas, pero más

\footnotetext{
${ }^{37}$ Han, 1992: 19.

${ }^{38}$ Ibídem: 14.

${ }^{39}$ Aunque pueden encontrarse muchas referencias a esta fábula, traslado las palabras de un publicista en el periódico El Mundo: "Imagine una cazuela llena de agua, en cuyo interior nada tranquilamente una rana. Se está calentando la cazuela a fuego lento. Al cabo de un rato el agua está tibia. A la rana esto le parece agradable, y sigue nadando. La temperatura empieza a subir. Ahora el agua está caliente. Un poco más de lo que suele gustarle a la rana. Pero ella no se inquieta y además el calor siempre le produce algo de fatiga y somnolencia. Ahora el agua está caliente de verdad. A la rana empieza a parecerle desagradable. Lo malo es que se encuentra sin fuerzas, así que se limita a aguantar y no hace nada más. Así, la temperatura del agua sigue subiendo poco a poco, nunca de una manera acelerada, hasta el momento en

que la rana acaba hervida y muere sin haber realizado el menor esfuerzo para salir de la cazuela. Si la hubiéramos sumergido de golpe en un recipiente con el agua a cincuenta grados, ella se habría puesto a salvo de un enérgico salto.

Es un experimento rico en enseñanzas. Nos demuestra que un deterioro, si es muy lento, pasa inadvertido y la mayoría de las veces no suscita reacción, ni oposición, ni rebeldía.", en Calvo, Shermann: "El triste final de la rana hervida", El Mundo, 7-09-2012.Disponible en http:/ / elmundo.com.sv/el-triste-final-de-larana- hervida. Consultado el 30-12-2014. Esta metáfora fue el punto de partida para una campaña publicitaria de claro tinte social, a favor de un referéndum en la Universidad de Sevilla, como puede verse en el vídeo que realicé para la misma: http://machacadas.blogspot.com.es/2013/11/somos-ranas-ono_5835.html.

${ }^{40}$ Ejemplo utilizado por Serres y retomado por Lévy en buena parte de su libro ¿Qué es lo virtual?.
} 
allá de eso, se intuía cierta participación de los visitantes, usuarios, espectadores... Con muchas de estas propuestas en red, el prestigio de la figura del autor pasaba a unos espectadores participantes que forman parte de la autoría de una obra en constante cambio. La verdadera revolución que representaba Internet partía de su propia concepción como red de redes. Si Borges o los miembros del grupo GRAV habían recurrido a la imagen del laberinto, con la red el laberinto se convertía en multidimensional, con millones de tránsitos y nudos posibles. El ejemplo también borgiano de las ruinas circulares, con un personaje que tiene el objetivo de crear un ser humano a través del sueño y que finalmente se hace consciente de que él mismo es una proyección, un sueño de otro, o del aleph, ese espacio donde se unen todos los espacios y tiempos concebibles implican una constatación de la realidad múltiple y compleja. Y tal vez lo radicalmente importante con respecto a las dinámicas de conflicto que hemos visto en los movimientos artísticos del siglo XX es que no puede establecerse una lucha semejante a la anterior, puesto que el terreno de Internet se inscribe en la virtualización, en la puesta en escena del mapa mental colectivo de una serie de ideas-conceptos-propuestas que difícilmente hubieran sido distribuidas desde los medios de comunicación de masas como la televisión, la prensa o la radio. Surgía así un comportamiento orgánico parecido al del cerebro. Pongamos un ejemplo. Para conseguir tener un comportamiento social en mi entorno (por ejemplo, mi país) como músico, tengo que haber aprendido de alguna manera a tocar, por ejemplo, la guitarra. Hay personas que han aprendido a tocar "de oído". Otras han pasado por el conservatorio. Evidentemente, si la naturaleza nos provee de esta facultad, cpor qué acceder a un sistema educativo para poder tocar la guitarra? El complejo sistema modular del cerebro nos enseña que un mismo comportamiento en la vida cotidiana puede responder a distintas corrientes de sinapsis neuronales. Para aprender a tocar la guitarra en el conservatorio, existe todo un entramado lógico de comprensión de la música. El aprendizaje más intuitivo de oído parece conllevar distintos procesos mentales y diferentes "tránsitos" en las corrientes sinápticas. Este hecho también ha sido manifestado en la investigación neuronal. Ciertos individuos que tienen una parte del cerebro dañado no pueden ejecutar ciertas acciones. Sin embargo, en la fase de recuperación es posible que tales individuos activen otras corrientes sinápticas y aunque parte del neocórtex siga efectivamente dañada, su cerebro ha buscado otro "camino" que da como resultado que el paciente pueda ejecutar las acciones o tener los comportamientos que en principio se pensaba que estaban asociados a esa parte concreta del cerebro. Los apasionantes casos clínicos analizados por el neurólogo Oliver Sacks abren un campo de investigación en la creatividad del ser humano. Un antropólogo en Marte, El hombre que confundió a su mujer con un sombrero y en especial Musicofilia, relatos de la música y el cerebro darían que investigar mucho más de lo que se puede presentar en este artículo.

Si con los MCM del siglo XX la direccionalidad emisor-receptor era evidente, con Internet y los smartphones es perfectamente posible convertirse en emisor. Los caminos carecen de una direccionalidad establecida. Los más transitados pueden verificar cierta "emergencia" social.

Ahora es como si aquellas iniciales obras interactivas se hubieran multiplicado y costara trabajo que se diera la emergencia, por pura saturación.

El hecho de que todo el ser humano fuera ya un artista, parecía más cercano al fin ideal de Internet como medio igualitario. Esta apertura y los lenguajes manejables proporcionaban la posibilidad de que cualquier persona pueda adecuarse al papel del artista como innovador de los lenguajes y experimentador. Las posibilidades de experimentación se multiplicaban exponencialmente. Se creaban géneros hiperhíbridos, cercanos a un pensamiento multidimensional. Pero todo el mundo puede crearlos. Y es esa intoxicación de datos lo que marca la sociedad que vivimos hoy en día. Y el movimiento de esos datos. Para la generación de discursos, el yo llega a colapsarse en esa lucha por ser más que el otro, más que la masa indiferenciada de los cómics de Mccloud, y ése es un ejercicio 


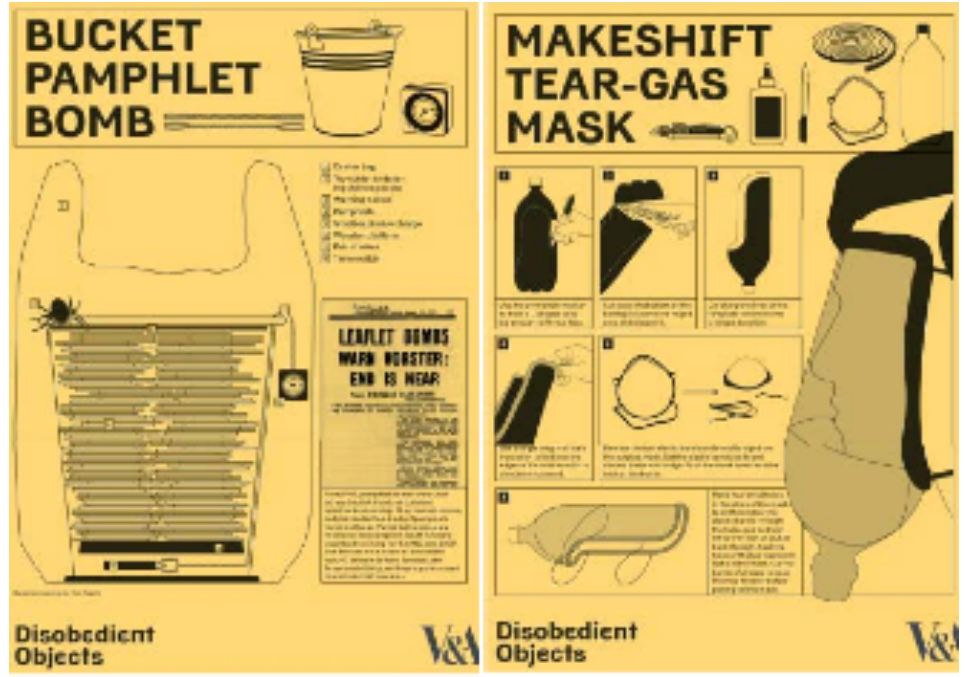

Fig. 2 y 3.Ejemplos de objetos en la exposición Disobedient objects. 2015.

narcisista, que no tiene límites. Por eso entiendo que el límite como especie global debe darlo nuestro planeta, porque es el contexto de la sociedad globalizada.

En este contexto, ¿qué debe ser el arte desde una perspectiva ecológica sino un motor para la transformación de una sociedad en riesgo de saturación? Por eso la exposición Objetos desobedientes, que se corona con una pancarta en que reza "Capitalism is Crisis", proyectaba entre otras imágenes, la de los asaltos festivos a sucursales de CajaMadrid, en la lucha contra Bankia, y ofrece por internet folletos sobre cómo fabricar bombas-folletos, utilizadas para esparcir publicidad contra regímenes opresores, o instrucciones para hacer máscaras de gas para los manifestantes. Y creo que ése es el verdadero legado de la acción colectiva, de esa humanidad que se ya se ha visto a sí misma desde que se realizó la primera fotografía del globo terráqueo. Retomar el arte como una dimensión del ser humano, más que como el arte de quienes parten de la imagen del artista como conservador de privilegios es la gran cuestión. Por eso hay que alabar la desobediencia, y en especial la exposición Objetos desobedientes, por servir, dentro de un espacio artístico, de extensión de la idea de una lucha global por una humanidad más justa. Los objetos desobedientes eran el testimonio de una lucha que emerge de la acción colectiva, y también objetos-vínculo, de esos que construyen identidad por emergencia. 
Bibliografía

Benjamin, W.: "La obra de arte en la época de su reproductibilidad técnica". En Discursos Interrumpidos. Madrid, pp.15-57. (1973)

De Micheli, M.: Las vanguardias artísticas del siglo XX. Madrid: Alianza Forma. (1979)

Eco, U.: Obra abierta. Barcelona: Planeta-Agostini. (1984)

Gálvez, A.M.: Posicionamientos y puestas en pantalla. Análisis de la producción de sociabilidad en los entornos virtuales. Tesis Doctoral. Universitat Autònoma de Barcelona. (2004)

Gregory, R. L. (ed.): Diccionario Oxford de la mente. Madrid: Alianza Diccionarios. (1995)

Han, Byung Chul: La sociedad del cansancio. Barcelona: (2012)

Herder. H., Byung C.: La agonía del Eros. Barcelona: (2014)

Herder. H., Byung C." ¿Por qué hoy no es posible la revolución?”. El País, 3-10-2014. Disponible en http://elpais.com/elpais/2014/09/22/opinion/1411396771_691913. html. Consultado el 30-12-2014.

Huidobro, V,: "El Creacionismo", en Manifestes, 1925. Manifiesto rescatado de http://www.vicentehuidobro.uchile.cl/manifiesto1.htm. Consultado el 08-02-2015.

Kerckhove, D.: La piel de la cultura. Investigando la nueva realidad electrónica. Gedisa: Barcelona. (1999)

Kleinsmith, L. J.; Kerrigan, D.; Spangler, S.: "Entendiendo el cáncer". Disponible en http://press2.nci.nih.gov/sciencebehind/cancersp/cancersp01.htm(14-04-2004)

Lévy, P.: ¿Qué es lo virtual? Barcelona: Paidós Multimedia. (1999)

Marina, J.A: Elogio y refutación del ingenio. Barcelona: Anagrama. (1992)

Marina, J.A.: Teoría de la inteligencia creadora. Barcelona: Anagrama. Mccloud, S. (2001): La revolución de los cómics. Norma. Biblioteca Creativa no 6. Barcelona. (1993)

Núñez, A.: "Fórum Universal de las Culturas. Barcelona: La fiesta continúa". En El periodista. La voz atrevida. Año 3, n49, Domingo 23 de Noviembre de 2003. http://www.elperiodista.cl/newtenberg/1529/article-55995.html (06-05-2004) (2004)

Padilla Obregón, F.: "Inteligencia Colectiva e Inteligencia Conectada". Disponible en http://www.javeriana.edu.co/Facultades/C_Sociales/Facultad/sociales_virtual/trabajo04.htm.2002.(Consultadoel0 6-05-2004)

Vázquez Medel, M.A. (Dir.) (2003): Teoría del Emplazamiento: Aplicaciones e Implicaciones. Sevilla: Alfar. (2003) 